\title{
Radioimmunoassay of androstenedione and testosterone in cow plasma at the time of luteolysis and oestrus
}

\author{
A. J. Peterson, R. J. Fairclough and J. F. Smith \\ Ministry of Agriculture and Fisheries, \\ Research Division, Ruakura Animal Research Station, Hamilton, New Zealand
}

\begin{abstract}
Summary. Androstenedione and testosterone were measured by radioimmunoassay after chromatography on micro-columns of Lipidex-5000 in jugular plasma samples taken every $2-3 \mathrm{~h}$ at the time of luteolysis and oestrus in 3 dairy cows. The concentrations of androstenedione and testosterone varied between 5 and $60 \mathrm{pg} / \mathrm{ml}$ and 5 and $80 \mathrm{pg} / \mathrm{ml}$ respectively and no consistent pattern in the fluctuations of either steroid was observed.
\end{abstract}

Luteolysis in the cow is accompanied by peaks of the 13,14-dihydro-15-keto metabolite of prostaglandin F-2 $\alpha$ in the peripheral circulation (Peterson, Fairclough, Payne \& Smith, 1975; Kindahl, Edqvist, Granström \& Bane, 1976). The plasma peak of oestradiol-17 $\beta$ subsequent to luteolysis plays an obligatory role in behavioural oestrus (Robertson, 1969). The influence of other hormones, however, is uncertain. Kanchev, Dobson, Ward \& Fitzpatrick (1976) have reported that large peaks of plasma testosterone precede the decline in plasma progesterone and suggested that testosterone may be involved in the onset of luteolysis in the cow. These results differed from those of Shemesh \& Hansel (1974) who did not detect any testosterone peaks of such magnitude over the same period. To resolve this discrepancy we determined the plasma concentrations of androstenedione and testosterone in 3 non-lactating multiparous dairy cows sampled at frequent intervals about the time of luteolysis and oestrus.

\section{Materials and Methods}

Blood samples were obtained by jugular venepuncture every $2 \mathrm{~h}$ during the day and every $3 \mathrm{~h}$ during the night. Oestrus (Day 0 ) was detected by using a vasectomized bull fitted with a chin-ball harness (Peterson et al., 1975). The plasma was extracted with 6 volumes of diethyl ether (Fluka) and chromatographed on micro-columns of Lipidex-5000 (Fairclough, Rabjohns \& Peterson, 1977) developed with hexane: chloroform $(80: 20 \mathrm{v} / \mathrm{v})$ containing $0.1 \%$ dimethyldisulphide (Lindqvist, Sjögren \& Nordin, 1974). The androstenedione and testosterone fractions thus separated were subjected to radioimmunoassay with antisera raised against androstenedione-6 $\beta$-succinyl-BSA and testosterone-3(O-carboxymethyl)-oxime-BSA. Of all the $\mathrm{C}_{18}, \mathrm{C}_{19}$ and $\mathrm{C}_{21}$ steroids examined, only 17ß-hydroxy-5androstane-3-one showed significant cross-reactivity $(100 \%)$ with the testosterone antiserum (Nieschlag \& Loriaux, 1972). However, there are negligible amounts of this steroid in cow plasma (Kanchev et al., 1976). Testosterone showed the greatest cross-reactivity $(0 \cdot 2 \%)$ of all the steroids tested with the androstenedione antiserum. The mean recovery ( \pm s.d.) of tritiated androstenedione added to 10 samples $(1 \mathrm{ml})$ of ovariectomized cow plasma after extraction and column chromatography was $70 \pm 3 \%$. The mean recovery of tritiated testosterone determined in a similar way was $62 \pm 2 \%$. Over the range of $10-50 \mathrm{pg}$, recoveries of androstenedione and testosterone were of the order of $67 \pm 5$ to $74 \pm 6 \%$ and $58 \pm 10$ to $64 \pm 10 \%$, respectively. The between-assay coefficient of variation calculated from control samples run in duplicate with each assay was $14 \%$ for androstenedione and $15 \%$ for testosterone. The within-assay coefficient of variation of 50 duplicates analysed for both steroids chosen at random from 10 consecutive sets of assays was $7 \cdot 5 \%$ for androstenedione and $9.2 \%$ for testosterone. The sensitivity of the method, as defined by Ekins (1970), was $4 \mathrm{pg}$ for androstenedione and $6 \mathrm{pg}$ for testosterone. 


\section{Results}

The changes in jugular concentrations of androstenedione and testosterone during luteolysis and oestrus are shown in Text-fig. 1. Like Kanchev \& Dobson (1976), who reported little variation in androstenedione levels in daily blood samples collected throughout the entire oestrous cycle, we observed no consistent pattern in the fluctuations of androstenedione. The androstenedione concentrations measured are at the low end of the range reported by Saba, Cunningham \& Millar (1975) and Kanchev \& Dobson (1976). We also observed no consistent pattern in the levels of testosterone, although the concentrations fell within the range of those reported by Shemesh \& Hansel (1974), Saba et al. (1975) and Kanchev et al. (1976).
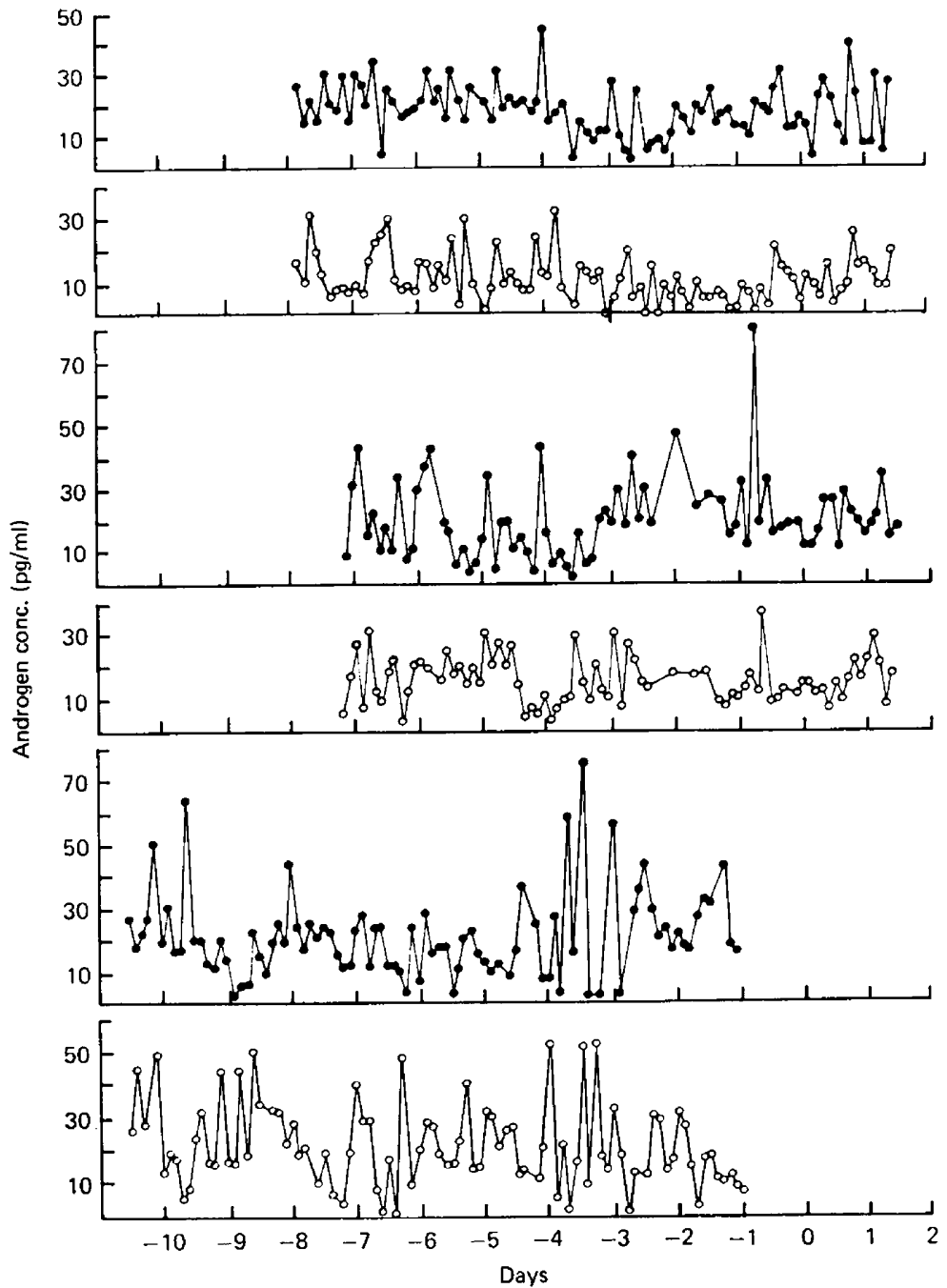

Text-fig. 1. Jugular concentrations of plasma androstenedione $(0)$ and testosterone $(\bullet)$ in three dairy cows bled every 2-3 h during the time of luteolysis and oestrus (Day 0 ).

\section{Discussion}

The very high peaks of testosterone ranging from 402 to $3700 \mathrm{pg} / \mathrm{ml}$ observed by Kanchev et al. (1976) between 5 and 8 days before oestrus are difficult to explain against the findings of Shemesh \& Hansel (1974) and the present results. Kanchev et $a_{n}$ (1976) considered that these peaks preceded the $16 \mathrm{AM}$ 
day on which progesterone concentrations began to decrease. Progesterone levels fluctuate widely during the late luteal phase of the cow (Peterson et al., 1975; Kindahl et al., 1976) and from sampling only once daily it is impossible to determine accurately the onset of luteolysis. We found no relationships between androgen and progesterone levels during the period of sampling every $2-3 \mathrm{~h}$ throughout the time when luteolysis began (Peterson et al., 1975). Kanchev et al. (1976) and Shemesh \& Hansel (1974) also reported a pro-oestrous peak of testosterone. Our present data, based on a much more intensive sampling regimen than the daily samples taken by Kanchev et al. (1976) and Shemesh \& Hansel (1974), do not confirm the occurrence of any androgen peaks during luteolysis and oestrus.

The corpus luteum and ovarian follicle of the cow are able to synthesize testosterone in vitro (Shemesh, Hansel \& Concannon, 1975; Mori, 1975), but the contribution of ovarian androgens to the peripheral pool of androstenedione and testosterone in vivo is unknown. The absence of any rise of androstenedione or testosterone at a time when the concentrations of oestradiol-17 $\beta$ reach peak values (Peterson et al., 1975) suggests that the preovulatory follicle contributes little to the peripheral androgen pool.

We thank the staff at the Fertility Centre, Ruakura, for help in the management and blood-sampling of cattle; Patricia Woolford and Pamela Lane for excellent technical assistance; and Dr E. Nieschlag, Dusseldorf, for his generous gift of the testosterone antiserum. The androstenedione antiserum (No. 861) was obtained from Dr G. D. Niswender, Fort Collins, Colorado.

\section{References}

EkINs, R.B. (1970) Theoretical aspects of saturation analysis. Acta endocr., Copenh., Suppl. 147, 11-36.

Fairclough, R.J., Rabjohns, M.A. \& Peterson, A.J. (1977) Chromatographic separation of androgens, estrogens and progesterones on hydroxyalkoxypropyl Sephadex $\left(\right.$ Lipidex $\left.^{\mathrm{R}}\right)$. J. Chromatog. 133, 412-414.

KANCHEV, L.N. \& DoBson, H. (1976) Plasma concentration of androstenedione during the bovine oestrous cycle. J. Endocr. 71, 351-354.

Kanchev, L.N., Dobson, H., WaRd, W.R. \& FitzPATRICK, R.J. (1976) Concentration of steroids in bovine peripheral plasma during the oestrous cycle and the effect of bethamethasone treatment. $J$. Reprod. Fert. 48, 341-345.

Kindahl, H., EdQvist, L.E., Granström, E. \& Bane, A. (1976) The release of prostaglandin $F_{2 \alpha}$ as reflected by 15-keto-13,14-dihydroprostaglandin $F_{2 \alpha}$ in the peripheral circulation during normal luteolysis in heifers. Prostaglandins 11, 871-878.

I.INDQVist, B., SJögReN, I. \& NoRdIN, R. (1974) Preparative fractionation of triglyceride mixtures according to acyl carbon number using hy- droxyalkoxypropyl Sephadex. J. Lipid Res. 15, 65-73. MORI, T. (1975) Steroid hormone formation in bovine ovarian follicles. Endocr. jap. 22, 361-366.

NieschlaG, E. \& LoRiaux, D.L. (1972) Radioimmunoassay for plasma testosterone. $Z$. klin. Chem. klin. Biochem. 10, 164-168.

Peterson, A.J., Fairclough, R.J., Payne, E. \& Smith, J.F. (1975) Hormonal changes around bovine luteolysis. Prostaglandins 10, 675-684.

RoBertson, H.A. (1969) The endogenous control of oestrus and ovulation in sheep, cattle and swine. Vitams Horm. 27, 91-130.

Saba, N., Cunningham, N.F. \& Millar, P.G. (1975) Plasma progesterone, androstenedione and testosterone concentrations in freemartin heifers. $J$. Reprod. Fert. 45, 37-45.

Shemesh, M. \& HANSEL, W. (1974) Measurement of bovine plasma testosterone by radioimmunoassay (RIA) and by a rapid competitive protein binding (CPB) assay. J. Anim. Sci. 39, 720-724.

Shemesh, M., Hansel, W. \& Concannon, P.W. (1975) Testosterone synthesis in the bovine corpus luteum. Biol. Reprod. 13, 490-493. 